\title{
Populism, Ideology and Contradiction: Mapping Young People's Political views
}

\author{
Gary Pollock, Tom Brock and Mark Ellison \\ Department of Sociology \\ Manchester Metropolitan University \\ Manchester \\ M15 6LL \\ G.Pollock@mmu.ac.uk
}

\begin{abstract}
Forms of populism have long been a component of modern political discourse and systems where democracy relies upon popular legitimacy. There is, however, an uneasy relationship between some widely held views of 'the people' and the parties which seek to govern them. Contemporary academic and political discourse on populism often equates these views with right-wing politics, whilst some radical scholars, suggest that these views, whilst controversial, are nonetheless examples of democratic expression. Using survey evidence from fourteen European countries, we show that young people take up a mixture of political positions, some of which are strongly associated with indices of populism - cynicism, authoritarianism, nativism, xenophobia others of which do not map neatly onto the typical 'left-right' spectrum. We find evidence that some young people hold contradictory, often conflicting political viewpoints, which are reflective of the historical and cultural contexts of each location rather than of a 'populist' ideology. Where some theorists might use the term 'populism' pejoratively to denote a poorly and emotively grounded political ideology, we argue that this description denies its democratic legitimacy, as evidence suggests that young people draw on populist rhetoric to articulate views that are more reflective of local and regional concerns.
\end{abstract}

\section{Introduction}

The rise of political parties described as 'populist' has been widespread throughout Europe in recent years. In many countries such parties now represent a more significant force, in terms of electoral success, than at any time since the end of WW2. Over the past twenty years populism has become a structural feature of most European party political systems, arguably constituting a new party type across the political spectrum (Zaslove, 2008). As such, it has been suggested that it represents a fundamental challenge to contemporary democracy (Pinelli, 2011). Parties classified as 'populist' have been able to take significant numbers of MPs away from mainstream parties and in some countries they are able to enter into ruling coalition governments such as the Freedom Party in Austria 2000 to 2005. In some cases, the effect of this has been that populist parties now influence mainstream parties in their policy programme development (Jennings, 2011). This paper does not seek to 
explain why this has been the case; such an explanation would require a nuanced analysis of both the supply and demand related factors within any local historical context. It suggests, however, that the preconditions for such shifts in the political landscape can be illuminated through the exploration of empirically demonstrable demand related beliefs.

Much of the voluminous literature on populism discusses conceptual issues in an attempt to clarify precisely what is under analysis. Early work on populism shows a concern with a phenomenon which is regarded as orthogonal to the left-right spectrum (Worsley, 1969; Laclau, 1979). Understood thus, forms of populism have been seen as central to movements dedicated to promoting political developments that are of benefit to parts of the population in regions where large swathes feel the government is not representative of their concerns.

The extension of voting rights to wider society during the early parts of the twentieth century broadened the content of politics beyond the sectoral interests of elites in society. The roots of these changes, of course, lie in developments from the previous century such that change was gradual with no teleological trajectory (Tilly, 2004). There is no inevitable structure and trajectory for democracies, rather, they are built upon local and regional struggles, compromises and hegemonies, which means that the pace and type of politics that emerges is tied to cultural components that cannot be ignored (see, for example, Kopstein and Reilly, 2000).

Despite this local specificity, the element of populism that is most accepted as a core conceptual feature is its association with forms of anti-elitism and a cynicism towards those who are responsible for government. This can be seen in the works of Canovan (1999) and Laclau (2005), for whom, 'populism', refers to ways that individuals express their unfulfilled political demands collectively in the face of established structures of power and authority and dominant ideas and cultural values. Thus, for both, populism is intricately tied to issues of representation and democracy, as the people's concerns are a necessary part of the democratic process and must be heard. They differ on the extent to which populism is a good thing; Canovan $(1999: 3,10,16)$ refers to populism as the 'shadow' of democracy on more than one occasion, for example. Nonetheless, there is no pejorative connotation here; populism is still considered a legitimate component of political discourse if not its central element.

There is another tradition, however, whose tone can be said to create folk devils of those who subscribe to positions which are commonly referred to as populist. Ruzza (2009: 87), for example, suggests that the emergence of an uncivil society can be attributed to the 'anti-modern' thinking of political actors, whose 'territorial' and 'culturally exclusionist' behaviour render them populist and, ultimately, undemocratic. Other arguments that place populism in opposition to democracy can be found also in work of Bale (2013), Baggini (2013) and Fieschi (2004). 
In Hatred of Democracy, Jaques Rancière (2006: 80) points to the potential dangers and agendas that reside behind this academic dismissal of populist views. He writes that the term 'populism' is often used as a rhetorical strategy that silences dissent in relation to the prevailing consensus; the 'oligarch', as he calls it, of social and political science, works to govern without people, that is, 'without any dividing of the people; to govern without politics'. The implication of this, for Rancière is that if science cannot impress its vision of progress upon the people, then those people are dismissed as 'ignorant', 'backward' and attached to a past that is no longer in keeping with what the experts consider to be legitimate. Indeed, it is interesting that so little of the contemporary discourse is open to the possibility of populism as politics where populism is a form of political praxis (Laclau, 2005; Jansen, 2011), or of populism as a phenomenon that may exist comfortably on the left as well as the right (Deiwiks, 2009; March, 2011; Moffit and Tormey, 2014).

The divergent perspectives on populism stem from uncertainties over how to define its boundaries. For example, Brett (2013) describes populism as a 'stretched concept', having been adapted by different researchers for different purposes. According to Brett (2013: 410), populism has been used by academics, policy-makers and politicians as a synonym for 'popularity' or to denote a wide-range of political positions from 'violent racism to agrarian socialism'. The term has been used also to refer to 'democratic argument' (Painter, 2013) indicating the need to recognise that populism is as much a form of rhetoric, than strictly an ideological position. Indeed, populism refers to the rule of the people and, thus, implicitly acknowledges the need for democratic and debate and struggle. Similarly, the literature is divided over the extent to which populism is a problem for democracy; while some see it as a destabilising influence on political institutions others view it as a component capable of engaging the wider population in political debate (Vasilopoulou et al., 2014). Arguably, understandings of populism are bound to contemporary manifestations of democracy; an 'antagonistic discontinuity' between the two renders fruitless attempts to close down populist discourse (Abts and Rummens, 2007).

We take as our starting point the need to objectively examine forms of populism as legitimate political positions within a pluralist discourse. According to Laclau and Mouffe (1984) social divisions are inherent in the very possibility of a democratic politics. One cannot simply erase from political discourse those positions or perspectives that one disagrees with. Such a move chimes with a blurring of the frontiers between left and right in recent decades, a move which has been regarded as positive (Giddens, 1994, 1998) but which has arguably undermined positive elements that radical and plural democratic forms of debate can take. Our understanding of that which is political is informed by Mouffe's work on agonism where she argues that there is a need for room within democracy for open debate where there is discursive space given to all positions within a system of broad toleration (Mouffe, 2000, 2005). Drawing on Schmitt's (1996) 'friend-foe' distinction, Mouffe argues that central to politics is 
the need to be able to passionately articulate what and whom you oppose with the consequence that to deny the possibility of this will on the one hand 'sanitize' politics, that is, make it dull and uninteresting and, on the other, will drive political passions elsewhere (Mouffe, 2002). Similarly, Canovan's (1999) work argues that there is a need to regard 'the people' and their concerns as legitimate. Unfortunately, she later undermines this claim, when, in her conclusion, she suggests that whilst the people's concerns are a necessary part of the democratic process, they may need to be kept in check to further the 'redemptive' character of democracy. Indeed this is something that is typical of contemporary academic discourse where the concerns of 'the people', whilst 'real' and 'legitimate' in their democratic expression, are viewed as undesirable and, ultimately, equated with right-wing politics (see: Mudde, 2004, 2007).

As Laclau and Mouffe (1985) note, such political essentialism is problematic because it closes down the space to give sufficient attention to how an individual's politics reflects their struggle with structural positions that are local and specific. For Laclau and Mouffe these 'points of antagonism' take on different 'forms of struggle' as individuals develop political views that then allow them to interpret and respond to their structural positions within any given social formation. Of course, much of this thinking - about the value of autonomy and the importance of context - extends from Gramsci (1971) who suggested that counter-hegemonic forces should not concentrate their attack on a single front, against one seat of power, but, rather, should engage in a variety of progressive struggles according to its own contextually-specific logic (Laclau and Mouffe, 1985: 178). In other words, local struggles reflect contextually-specific antagonisms that have provided the grounds for locallysituated groups to organise into counter-hegemonic movements. For Laclau and Mouffe, the scale and scope of these struggles vary depending on whether the antagonisms are represented more broadly. Thus, a national movement may be considered 'local' in the sense that it reflects contextually-specific concerns that need to be addressed. The important point of Laclau and Mouffe is that in focusing on context one reserves a space for plurality and autonomy among the elements for the creation of a counter-hegemonic bloc and this is central for the sort of innovation in tactics needed to respond effectively to the specificity of contemporary antagonisms (see Brock and Carrigan, 2014; also Smith, 2012).

This position is well supported in classical liberal texts (eg, Mill, 1972) but, more recently, in the arguments of John Keane (2009: 855), who argues that the democratic ideal is linked to an active commitment to 'pluriversality' - the need to 'empower people everywhere, so that they can get on with living their diverse lives on earth freed from the pride and prejudice of moguls, magnates, tyrants and tycoons' [emphasis added].

This is our point of departure. We look to research on young people's political views in 14 European countries to consider the important role that local and regional factors play in explaining the differences in views between these locales whilst also pausing to consider the contradictions that emerge within 
them. In other words, the empirical realities of young people's politics leads us to question the myth that the term populism peddles: that ideology is a wellintegrated system of beliefs that adequately pits the concerns of the 'ordinary people' against some other social group. Rather, we would suggest that populisms emerge to reflect the local and regional conditions that prompt young people to problematise concrete problems.

This is significant for us because we wish to challenge academic discourse that has a strong normative perspective and often denies open debate over the legitimacy of views it finds undesirable. In this discourse, it is widely understood that the propensity of the general population towards particular policies often described as populist is high but that the failure of so called populist parties to mobilise this support is the reason why such views never actually reach the statute books (Mudde, 2007). Looking to the views of young people, we hope to show why such a conclusion necessarily implies possible power imbalances between how young people's political views are treated across Europe.

In a recent study of voters (Akkerman et al., 2014), evidence suggests that populist views are associated with a propensity for voting for populist parties. While this may seem tautological, attitudes do not always translate into behaviour. The evidence examined in this paper contributes to the literature on the demand side of populism, through an engagement with individual views on four specific dimensions associated with both populism and the extreme right wing: xenophobia' ${ }^{1}$, cynicism, authoritarianism and nativism. This four dimensional representation of components of (right-wing) populism has been used elsewhere (Mudde, 2007; Harrison and Bruter, 2011). We argue that views expressed on these dimensions, whatever their content, are important indicators of the political concerns of these young people. We are interested in the extent to which views are independent of locale or are regionally specific and the extent to which dimensions of populism are associated with the leftright political spectrum, in particular its extremities. Finally we are interested in the ideological coherence, or rather the lack of it, when it comes to young people's 'populist' views.

The article thus tests the following three hypotheses:

Hypothesis 1: that dimensions of populism are locally specific.

Hypothesis 2: that populist views are orthogonal to the left right spectrum.

Hypothesis 3: that there are ideological contradictions associated with those regarded as possessing populist views.

\section{Data and methods}

The MYPLACE questionnaire survey, explained in greater depth in the introduction to this volume is a common research instrument administered to a representative sample of 16-25 year olds in 30 separate locations in 14 
different countries. The data was collected between September 2012 and April 2013 , with an achieved overall sample of 16,935 . Each country selected two contrasting locations (with 4 in Germany: 2 in the old East and 2 in the old West) where the criteria for selection was that there were a priori reasons to suggest that the attitudes, behaviour and experiences of the young people would be different. This means that we have a range of research sites, each with distinct features which are unique to themselves and which require an understanding of local as well as national contexts to fully appreciate the reasons why young people hold the attitudes that they do. It is important to reiterate that these are a series of local case studies and not nationally representative results.

Four indices representing the aforementioned dimensions of populism (xenophobia, cynicism, authoritarianism and nativism) are created using a range of questions from the MYPLACE survey. While our analysis is embedded within a critical engagement with previous empirical work on populism we do not reject the use of these widely accepted measures. Our aim is to better understand the dynamics which contribute to widespread support for such indices of populism and to explore the legitimacy of these beliefs in mainstream political discourse. The questions used to construct these indices are presented in Appendix 1. All composite variables are justified on the basis of factor analysis, and internal reliability is measured using Cronbach Alpha or Person's r. All questions used were five point Likert scales which were recoded to 0 to 4 , summed and rescaled 0 to 1 , with a high score representing high levels on each index (see Appendix 1).

The central method used here to test the hypotheses are multilevel regression models (Hox, 2010; Heck et al., 2010) as these models are best able to articulate the structure of the research design. The 30 different research sites are selected in order to maximise variability within each country and it is a reasonable assumption to anticipate variability between countries.

Four models are presented, one for each of the dimensions described above. Final models with a common set of individual and contextual variables are shown in order to facilitate comparability of predictor variables.

\section{Findings}

The mean scores for each location on each of the four dimensions as well as the left-right scale are shown in Table 1 along with the overall grand mean. The dark shading indicates those locations which are in the upper quartile and the pale shading those that are in the lower quartile and thus highlight the locations where there are higher and lower average tendencies to have these views. Average levels of cynicism and nativism are high (0.692 and 0.705 respectively on a scale of 0 to 1 ), well above the centre of the scale, whereas the average for xenophobia $(0.544)$ is towards the centre of the scale and for authoritarianism (0.344) it is much lower. Almost all these figures are within one standard deviation of the mean, the exceptions being both Danish sites on 
the cynicism index and three of the German sites (not Bremerhaven) on the xenophobia index. It is inappropriate to draw strong conclusions from these figures as they represent the mean scores for each location independent from any other variable and are therefore sensitive to the distribution of the index within the location. They are of interest, however, in terms of the magnitude of the scores on the cynicism and nativism indices, both of which are a clear indication of the general strength of views across the board on these issues. Harrison and Bruter (2011) find the same but are more interested in regional variation as opposed to the absolute figure. Our belief is that the average magnitude is an important indicator of the breadth of populist views and as such shows that these dimensions, at least, must be regarded as central to personal political views and not some sort of aberration. It is also worth noting that all four German locations as well as both Danish ones have average scores below the grand mean on all four indices.

[Insert Table 1]

Each index is used as a dependent variable in a multilevel model and subject to analysis alongside a common set of independent variables. Table 2 shows that for all four models a multilevel model is justified and that in all cases that there is significant improvement in the fit of the model as both individual level and location specific variables are included.

[Insert Figures 1 to 4]

When the average location scores for authoritarianism, nativism and xenophobia are plotted alongside cynicism there is further reinforcement of the locational and regional structure of our data. While these spatial positions are insensitive to individual associations between these variables, such that no strong conclusions can be made from them, there are hints that there may be country specific averages where the paired locations are close to one another such as the locations in Greece, Spain, and Portugal. On the other hand there is also evidence of significant contrast between research locations within a country such as in the UK, Croatia and Latvia. These contrasts are a function of the choice of the research location, which sought to maximize within country contrasts.

\section{Multilevel models}

The importance of locally specific explanations is shown in two ways. Firstly, the intra class correlations for all four models demonstrate that it would be inappropriate to treat the data set as unstructured. The analysis must take into account that there are 30 different locations as by doing so the predictive power of the models is significantly enhanced by between 19 per cent and 31 
per cent (with xenophobia², 31 per cent; cynicism³, 22 per cent; authoritarianism ${ }^{4}, 26$ per cent and nativism;, 19 per cent respectively). Secondly, the inclusion of the country level variable indicating welfare state type (Esping-Andersen, 1990; Kääriäinen and Lehtonen, 2006) further improves the model in all cases and brings out a contrast between post-socialist countries and Nordic locations; the latter are less likely to be xenophobic, to display cynicism and authoritarian views. Similarly, respondents from German locations (a conservative welfare state region), when contrasted with postsocialist ones, are less likely to be xenophobic and authoritarian, although there is no significant difference in terms of cynicism. There is, however, a tendency for respondents in all four German locations (including those in what used to be East Germany) to be less nativist than in post socialist countries. On this measure, eastern Germany is an outlier compared to other post socialist countries. The other findings of significance in terms of welfare state regions is the contrast between Mediterranean locations and post-socialist ones where the former are more likely to display cynicism but less likely than Mediterranean locations to display authoritarian tendencies. Finally, our data showed no significant differences between the UK locations (liberal welfare state region) and the post socialist ones.

\section{[Insert Table 2]}

Our second hypothesis, on the orthogonality between populism and the leftright spectrum, is tested using the question where respondents indicate where they are on a 0 to 10 scale. We have simplified this into four categories: 'clear' left' (scores 0-2); 'clear right' (scores 8-10); 'centre' (scores 3 - 7); and 'don't know' using the central 'between clear left and right' category as the reference. This variable is an indication of a personal position on a political scale allowing for expressions of extremity. Thirteen percent of the distribution is 'clear left' and 11 per cent 'clear right' using this method.

The results show that there is a strong relationship between respondents' stated position on the left-right spectrum and their position on three of the four indices xenophobia, authoritarianism and nativism - with those on the clear right scoring high and the clear left scoring low. In terms of these three dimensions there is clear evidence that there is a relationship. On the third index on cynicism the findings are reversed with those on the left significantly more likely to be cynical and those on the right less likely, though this result is not significant. This complex picture can be interpreted to show that the hypothesis of independence between these four dimensions and the left-right spectrum cannot be fully supported. However, in terms of confirming or refuting a definition of populism focusing on anti-elitism - measured here by cynicism - it is possible to conclude that there is no association between those who say they are on the clear right (when compared to those in the centre of the political spectrum) and their cynicism. In fact, although the data are less clear, cynicism would appear to have the opposite political spectrum connotations compared to the other three dimensions. What it is possible to assert, therefore, is that because there is no differentiation between those on 
the clear right and those in the centre in terms of cynicism, equating cynicism with those on the right is incorrect.

\section{[Insert Table 3]}

The final hypothesis tests the extent to which we can see ideological coherence within the populism indices. This is measured using the respondents' answers to a question on different economic policies where what are traditionally understood as economically left wing perspectives - 'Competition is harmful, it brings out the worst in people' and 'Incomes should be made more equal' contrast with economically right wing perspectives - 'The unemployed should have to take any job available or lose their unemployment benefits' and 'Private ownership of business and industry should be increased'. For three of the models the indices show that both the economically left and right wing variables are positively associated with high scores for xenophobia, authoritarianism and nativism. For all three of these models, respondents scoring highly display both left and right wing ideological preferences. For the cynicism index, however, there is a significant association between a high score and those supporting economically left wing policies. We therefore feel that there is strong support for our hypothesis that when examining these four dimensions that these young people often hold positions which are contradictory in terms of traditionally understood economic ideologies.

When examining the individual level socio-demographic predictors, gender was significant, with males scoring higher than females and, therefore, more likely to display xenophobia, cynicism and authoritarianism tendencies. The age variable shows a negative significant effect; slightly older young people tend to score lower on the xenophobia, authoritarianism and nativism scales. However, the reverse is true with cynicism where the model suggests that young people at the upper end are more likely to be cynical than their younger counterparts. Parental social class is also significant; xenophobia, authoritarianism and nativism are negatively associated with higher social classes.

Respondents who are more 'pro-democratic' are less likely to display xenophobic, authoritarian and nativist views than those who are less 'prodemocratic'. However, the opposite is true with cynicism where young people who score highly on the pro-democracy index are more cynical. Young people who have higher levels of satisfaction with democracy in their country are significantly less cynical and have higher levels of nativism. Respondents who have greater trust in parliament are significantly less likely to display xenophobia and cynicism tendencies and are also significantly more likely to display nativism tendencies. 


\section{Discussion}

This paper has begun to map out young people's political views across Europe using the MYPLACE survey data. The analysis suggests that young people take up a mixture of political positions, some of which are strongly associated with indices of 'populism' - cynicism, authoritarianism, nativism and xenophobia. What we have shown, in the first instance, is that there is a tendency for these positions to map on to locations where there are regional or political histories that support the shaping of these views. Thus, locations within western European welfare states are less likely to be authoritarian, nativist and xenophobic when compared to post-socialist countries. We find evidence to support the claim that post-socialist countries are more likely to be populist than modern welfare states.

However, we should approach the term 'populism' with some critical distance, for where research has, in the past, equated it with political extremes, we have sought to view it within the wider context of democratic struggle. We have done this by opening up the term 'populism' to explore; i. local and regional variations; ii. the statistical independence of political cynicism; and iii. ideological inconsistency. Rather than equate populism with either left or right wing ideology, we have tried to show that young people's political views are often plural and contradictory in nature. Young people's views do not do not always cohere into a single ideological project and this should be an understood and respected aspect of democracy (Rancière, 2006; Laclau, 2005).

While Mudde (2007) suggests that a focus on political parties is of greater importance than political attitudes in the extent to which they are able to mobilise views regarded as dangerous or inappropriate within contemporary democracy, we believe that it is important to study political views from a standpoint that accepts the legitimacy of individual viewpoints. It is arguably an indication of the failure of the contemporary democratic political system if the political views of people are regarded as secondary to an analysis of political parties. The danger here is obvious: that in focusing on political parties one closes down voices that seek to make difficult issues heard

In mapping young people's political views, we find evidence to suggest that there is a variability/plurality of populisms that young people deploy, across Europe, to contend with social and political issues that are local and regional in scope. This makes it difficult to essentialise what populism constitutes as young people's views comprise a variety of ideological elements - often contradictory - and this is why location and regional factors must be considered. Evidence shows that there is an important macro element to the shaping of young people's political views and this should be acknowledged when describing manifestations of populism.

Why are location and regional factors important when mapping young people's political views?

In approaching the term 'populism' from the perspective that it is a plurality, we have constructed a set of indices and tested them for local and regional 
variations, showing that young people's political views may be shaped by location and region. Thus, there is evidence to suggest that interesting similarities and differences occur between locations but also within locations. We would suggest that to attribute social, cultural and political contexts to explaining these differences would require further qualitative exploration. Yet, in opening up the possibility of local and regional variation, we suggest that there is evidence to support the argument that young people are voicing concerns that reflect their direct lived experiences.

This paper shows that many of the young people surveyed (indeed the majority in some regions) can be regarded as populist to the extent that there is a strong tendency to express a cynicism towards politicians and political institutions. The evidence is also clear that aggregate levels of nativism also tend to be quite high. On both dimensions, however, it is clear that there is a strong geographical pattern which must be understood within the political histories of the locations studied. At the same time we show the ways in which these young people are associated with further dimensions attributed to populism on the right wing. These often exist alongside an engagement in politics and political processes. These findings also demonstrate the importance of regional specificity; regions with similar historical trajectories and welfare regimes show similar patterns.

We believe our data supports our view that populism must be a plurality because it must recognise the many demands that popular subjects make in regard to local and regional issues. There is literature which suggests that political participation is geographically clustered and that citizens' participatory behaviour is heavily influenced by the behaviour of those who live in close proximity to them (Tam Cho and Rudolph, 2008; Kopstein and Reilly, 2000). Here, it is suggested that 'geographic diffusion' plays an important role in how norms, resources and institutions are diffused and how this leads to the construction of political democracies. Whilst it is not our intention to prove this claim, our evidence does highlight how locality influences young people's political views.

Following Laclau (2007), we suggest that until it is clear why these articulations (particular views) or representations (general positions) emerge - possibly as counter-hegemonic interventions of the right against the centre - then it is superficial to suggest that 'populism is on the rise'. In other words, our evidence suggests that such is the plurality of populist views that to grasp at an explanation of the 'rise' or 'fall' of populism requires a sophisticated analysis of the local and regional features that create the conditions for the emergence of such views. In the absence of such recognition, it is plausible that the current trend - of pathologising populist views - will continue. 'Populism-asradicalism' will continue as a strategy, of the Centre, that can be used to close down the conditions for the development of a specific dialectic that Mouffe sees as key to democracy - agonism. 
Why is it important that young people's views be considered orthogonal to the left-right spectrum?

It follows that young people's locally influenced concerns might not map neatly onto the typical 'left-right" spectrum given that variation between and within locations would mean that young people's views reflect a plurality that emerges to contest local and regional structures of power and authority. Thus, it makes sense that evidence shows populism to be partially independent from the left-right spectrum, as young people respond to a deep dissatisfaction with contemporary politics but in ways that mirror their local and regional concerns. In other words, it is possible to draw from the analysis the following point: cynicism is high across Europe but it is orthogonal to the left-right spectrum. This prompts questions about the failure of both left and right politics to capture the voices, concerns and imaginations of contemporary youth (see Patterson, 2014). This is important because it serves as an indication that populism is not wedded to a particular ideological project as is the case in literatures which equate it with left or right-wing politics. If it is the case that, for some, populism is not 'aligned' to a particular ideological project, then there is scope to explore whether some individuals consider their views to be 'populist' and, reflecting on hypothesis 1, how social, cultural and political contexts shape these views.

\section{Why is it important that young people's views are contradictory?}

Local issues will inevitably cut across issues of ideological coherence and the results show that young people's personal viewpoints can be informed by opposing ideologies. This is supported by the data, which suggest that young people often hold positions which are contradictory in terms of traditionally understood economic ideologies. Again, it is important not to delegitimise the agent in this context by suggesting that these contradictions emerge as a result of personal confusion or a problem with accepting change. Rather, it is plausible that these contradictions are normal expressions of a range of incompatible social logics and beliefs that provide common-'sense' with elements of incoherence (Laclau, 1984: 183, 185, 189-90). We would argue that these elements are a practical aspect of democratic struggle and might make it difficult for left and right-wing ideologies to capture young people's concerns and issues. Indeed, there is a sense in which we now need to consider how and why such concerns coalesce into what Laclau and Mouffe (1984:12930) refer to as a 'logic of equivalence' - a representative and democratic front for young people's political views whatever they may be.

Arguably 'populism' is, at best, a misnomer or, at worse, a rhetorical device that only serves to silence the voices of politicised young people. As a misnomer, we could argue that the term 'populism' does not capture the empirical realities of young people's political concerns. Drawing on the empirical research, we have shown that we need to pluralise how political dissent/assent is expressed - as populisms - in order to render explicit, analytically, the geospatial-historical conditions under which such views emerge. Indeed, we would suggest that the term populism is a misnomer precisely because it fails to capture the empirical complexities that exist when new belief systems emerge (or old belief systems re-emerge in new ways). If 
we recognise the pluralistic nature of political dissent/assent, then the term populism becomes a tool through which legitimate, democratic expressions (of concrete, local problems) become 'boxed-off' as illegitimate forms of political utterance, e.g. as populist attitudes which must not be platformed. In effect, such a rhetorical strategy only reifies the contradiction - of people's concerns $v s$. the hegemonic political centre - without resolving its necessary conditions for existence.

One question that is now common in the literature is to ask: are these views (of youth) either corrective or a threat to democracy? (Mudde and Kaltwasser, 2012). In response to this, we might suggest that if academics and politicians are uncomfortable with the pronouncements by right-wing parties, then it may be that this discomfort should prompt the creation of a critique of the centre as part of a wider engagement with the wider crises in Western democracy that the views of these young people reflect.

\section{Conclusion}

This paper has begun to map young people's political views across Europe by analysing survey data from locations within 14 European countries. Inspired by the argument that populist views are expressions of democratic struggle, not the views of a 'backward' or 'ignorant' people, we have tried to open up the definition of populism to the plurality that would follow should this be case. The analysis has provided evidence to this effect. There is local and regional variation in populist views and these views are themselves subject to pluralism and inconsistency. This is important because it presents a challenge to those who would use 'populism' as a convenient pejorative term to dissimulate young people's political views. Perhaps an even greater challenge is to find ways to create the conditions to accommodate ideological plurality and contradiction whilst at the same time facilitating populist perspectives as a legitimate component of mainstream discourse.

\section{References}

Abts, K. and Rummens, S., (2007), 'Populism Versus Democracy', Political Studies, 55: 405-424.

Akkerman, A., Mudde, C. and Zaslove, A., (2014), 'How Populist Are the People? Measuring Populist Attitudes in Voters', Comparative Political Studies, 47 (9): 1324-1353.

Baggini, J., (2013), A Very British Populism. Available at: http://counterpoint.uk.com/wpcontent/uploads/2013/09/507 CP RRadical UK Web.pdf Last Accessed: 20th September, 2014.

Bale, T., (2013), Countering Populism: Snog, Marry, Avoid? Available at: http://www.policynetwork.net/pno detail.aspx?ID=4374\&title=Countering-populism-Snog-Marry-Avoid- Last Accessed: 20th September, 2014.

Brett, W., (2013), 'What's an Elite to Do? The Threat of Populism from Left, Right and Centre', The Political Quarterly, 84 (3): 410-413.

Brock, T., Carrigan, M. 2014. 'Realism and contingency: a relational realist analysis of the UK student protests', Journal for the Theory of Social Behaviour, Early View Available at: http://onlinelibrary.wiley.com/doi/10.1111/jtsb.12076/abstract. Last accessed 6th December, 2014.

Canovan, M., (1999), 'Trust the people!: populism and the two faces of 
democracy', Political Studies, 47 (1): 2-16.

Deiwiks, C., (2009), 'Populism' Living Reviews in Democracy. Available

at:http://www.livingreviews.org//rd-2009-3. Last accessed: 14 August 2014,

Esping-Andersen, G., (1990), The Three Worlds of Welfare Capitalism, Princeton, N.J: Princeton University Press.

Fieschi, F., (2004), Fascism, Populism and the Fifth Republic: In the Shadow of Democracy, Manchester: Manchester University Press.

Giddens, A., (1994), Beyond Left and Right: The Future of Radical Politics, Cambridge: Polity.

Giddens, A., (1998), The Third Way: The Renewal of Social Democracy, Cambridge: Polity.

Gramsci, A. (1971), Selections from Prison Notebooks, London: Lawrence and Wishart.

Harrison, S. and Bruter, M., (2011), Mapping Right Wing Ideology, Basingstoke: Palgrave.

Heck, R. H., Thomas S. L. and Tabata L. N., (2010), Multilevel and longitudinal modeling with IBM SPSS, New York: Routledge.

Hox, J., (2010), Multilevel Analysis, Techniques and Applications. Second edition. New York: Routledge.

Jansen, R. S., (2011), 'Populist Mobilization: A New Theoretical Approach to Populism', Sociological Theory, 29 (2): 75-96.

Jennings, C., (2011), 'The good, the bad and the populist: A model of political agency with emotional voters', European Journal of Political Economy, 27: 621-624.

Kääriäinen, J. and Lehtonen, H., (2006), 'The Variety of Social Capital in Welfare State Regimes a Comparative Study of 21 Countries', European Societies, 8 (1): 27-57.

Keane, J., (2010), The Life and Death of Democracy. New York: Pocket Books.

Kopstein, J. and Reilly, D.A., (2000), 'Geographic Diffusion and the Transformation of the Postcommunist World', World Politics, 53 (1): 1-37.

Laclau, E., (1979), Politics and Ideology in Marxist Theory, London: Verso.

Laclau, E., (2005), On Populist Reason, London: Verso.

Laclau, E. and Mouffe, C., (1984), Hegemony and Socialist Strategy, London: Verso.

March, L., (2011), Radical left parties in Europe, London: Routledge.

Mill, J.S. (1972), 'On liberty' in Utilitarianism, Liberty, Representative Government. New York: Dutton

Mouffe, C., (2000), The Democratic Paradox, London: Verso.

Mouffe, C., (2002), Politics and Passions: The Stakes of Democracy, London: Centre for the Study of Democracy.

Mouffe, C., (2005), On the Political, London: Routledge.

Mudde, C., (2004), 'The Populist Zeitgeist' Government and Opposition, 39 (4): 542-563.

Mudde, C., (2007), Populist Radical Right Parties in Europe, Cambridge: Cambridge University Press.

Mudde, C. and Kaltwasser, C.R., (2012), ‘Exclusionary vs. Inclusionary Populism: Comparing Contemporary Europe and Latin America', Government and Opposition, 48: 147-174.

Painter, A. (2013), Democratic Stress, the Populist Signal and Extremist Threat. Available at: http://www.policynetwork.net/publications/4357/Democratic-stress-the-populist-signal-andextremist-threat. Accessed: 19.09.2014.

Patterson, C., (2014), 'Both the left and right are failing young people on jobs', The Guardian. Available at: http://www.theguardian.com/commentisfree/2014/jan/03/right-left-failing-youngpeople-jobs. Accessed: 24.09.2014. 
Pinelli, C., (2011), 'The Populist Challenge to Constitutional Democracy', European Constitutional Law Review, 7 (1): 5-16.

Rancière, J., (2006), Hated of Democracy. London: Verso.

Ruzza, C., (2009), ‘Populism and euroscepticism: Towards uncivil society?’ Policy and Society, 28: 87-98.

Schmitt, C., (1996 [1932]), The Concept of the Political, Chicago IL: The University of Chicago Press.

Smith, A.M., (2012), Laclau and Mouffe: The Radical Democratic Imaginary, Routledge: London.

Tam Cho W.K. and Rudolph, T.J., (2008), 'Emanating Political Participation: Untangling the Spatial Structure Behind Participation', British Journal of Political Science, 38 (2): 273 - 289.

Tilly, C., (2004), Contention and Democracy in Europe 1650-2000, Cambridge: Cambridge University Press.

Vasilopoulou, S., Halikiopoulou, D. and Exadaktylos, T., (2014), ‘Greece in Crisis: Austerity, Populism and the Politics of Blame', Journal of Common Market Studies, 52 (2): 388-402.

Worsley, P., (1969), 'The Concept of Populism' in Ionescu, G. and Gellner, E. (eds), Populism - Its Meanings and National Characteristics, London: Weidenfeld and Nicolson.

Zaslove, A., (2008), 'Here to Stay? Populism as a New Party Type', European Review, 16 (3): 319-336. 


\section{Appendix 1}

Dependent variable construction

\begin{tabular}{|c|c|c|}
\hline Questions & Factor & $\begin{array}{l}\text { Cronbach } \\
\text { alpha/Pearsons } r\end{array}$ \\
\hline $\begin{array}{l}\text { Consider the following statements and } \\
\text { indicate whether you agree or disagree: } \\
\text { 'Foreigners should not be allowed to buy } \\
\text { land in [COUNTRY]' } \\
\text { Do you agree or disagree with the following } \\
\text { statements? } \\
\text { '[COUNTRY] should have stricter border } \\
\text { controls and visa restrictions to prevent } \\
\text { further immigration'. } \\
\text { 'When jobs are scarce, employers should } \\
\text { give priority to [COUNTRY] people over } \\
\text { foreign workers' } \\
\text { Five point Likert scales 'agree' to 'Disagree', } \\
\text { recoded } 0-4 \text {, summed and rescaled } 0-1 \\
\text { with a high score indicating xenophobia. }\end{array}$ & $\begin{array}{l}\text { Xenopho } \\
\text { bia }\end{array}$ & $\begin{array}{l}\text { Alpha }=0.658, \\
\text { varies from } \\
0.330 \text { (Georgia) } \\
\text { to } 0.710 \\
\text { (Finland) }\end{array}$ \\
\hline $\begin{array}{l}\text { Do you agree or disagree? Politicians are } \\
\text { corrupt. The rich have too much influence } \\
\text { over politics. 1-5 Likert scale recoded to 0-4, } \\
\text { summed and rescaled } 0-1 \text {, high score } \\
\text { indicating high cynicism. }\end{array}$ & $\begin{array}{l}\text { Cynicis } \\
\mathrm{m}\end{array}$ & $\begin{array}{l}r=0.473, \text { varies } \\
\text { from } 0.29 \text { in } \\
\text { Spain and } \\
\text { western } \\
\text { Germany to } \\
0.555 \text { in Croatia }\end{array}$ \\
\hline $\begin{array}{l}\text { I am going to describe various types of } \\
\text { political systems and ask what you think } \\
\text { about each as a way of governing this } \\
\text { country. For each one, would you say it is a } \\
\text { very good, fairly good, fairly bad or very bad } \\
\text { way of governing the country? } \\
\text { Having a strong leader who is not } \\
\text { constrained by parliament } \\
\text { Having the army rule } \\
5 \text { point scale of 'good' to 'bad', recoded } 0-4 \text {, } \\
\text { summed and rescaled } 0-1 \text { with a high score } \\
\text { indicating tendency to 'good' }\end{array}$ & $\begin{array}{l}\text { Authorit } \\
\text { arianism }\end{array}$ & $\begin{array}{l}\mathrm{r}=0.471, \text { varies } \\
\text { from } 0.22 \text { in } \\
\text { Portugal to } 0.514 \\
\text { in western } \\
\text { Germany }\end{array}$ \\
\hline
\end{tabular}




\begin{tabular}{|l|l|l|}
\hline Some people say the following things are & Nativism & Alpha $=0.685$, \\
important for being a citizen of [COUNTRY]. & & Varies from \\
Others say that they are not important. How & & 0.610 in western \\
important do you think each of the following & & Germany to \\
is? & & 0.750 in Hungary \\
To have been born in [COUNTRY] & and Georgia \\
To be able to speak [THE & \\
NATIONAL LANGUAGE] & \\
To have at least one [COUNTRY] parent & \\
To respect [COUNTRY] political institutions & \\
and laws & \\
Five point Likert scale 'very important' to & \\
'not important at all' recoded 0-4, summed \\
and rescaled 0-1 with a high score indicating \\
a tendency towards importance. & \\
\hline
\end{tabular}




\section{Endnotes}

See Appendix for an explanation of how each of these dimensions is operationalized in this study.

2 Due to the high number of missing cases in some of the questions, 27 per cent of the cases were excluded from the regression analysis, leaving $\mathrm{n}=12,435$. The initial analysis of variance components reveals that $68.8 \mathrm{per}$ cent of variance in xenophobia can be explained by differences between individuals, whereas 31.2 per cent of the variance lies at the level of localities (intra-class correlation (ICC) $=0.312$ ) (Table 2 ). The substantial variation at the level of localities means that it is necessary to search for contextual variables that would help to explain it. Inclusion of the individual level variables resulted in a 7.6 per cent decrease of residual, individual level variance, and led to an even larger - 36.7 per cent reduction in intercept variance. This means that much of the observed differences between localities are due to the composition effect, ie differing individual characteristics of their young residents. In the next step, we added a number of contextual variables, which helped to achieve a massive 67.1 per cent reduction of intercept variance compared to the model containing only the individual level predictors - again, an improvement that is highly significant. This means that our selected contextual variables are capable of explaining a huge portion of the unexplained variation in xenophobia between localities. Only 9.3 per cent of unexplained variance remains at the level of localities, although it is still significant (at 0.01 level). The chi-square test of deviances $(\Delta d f=31, \Delta$ loglikelihood $=624.351)$ confirms that it is statistically significant.

3 Again, 26.3 per cent of the cases were excluded from the regression analysis due to missing values, leaving $n=12,484$. The initial analysis of variance components reveals that 77.8 per cent of variance in cynicism can be explained by differences between individuals, whereas 22.2 per cent of the variance lies at the level of localities (intra-class correlation (ICC) $=0.222$ ) (Table 2). The substantial variation at the level of localities means that it is necessary to search for contextual variables that would help to explain it. Inclusion of the previously described individual level variables resulted in a 13 per cent decrease of residual, individual level variance, and led to an even larger - 53.6 per cent reduction in intercept variance. It means that much of the observed differences between localities are due to the composition effect, ie differing individual characteristics of their young residents. In the next step, we added a number of contextual variables, which helped to achieve a massive 79.8 percent reduction of intercept variance compared to the model containing only the individual level predictors - again, an improvement that is highly significant. This means that our selected contextual variables are capable of explaining a huge portion of the unexplained variation in cynicism between localities. Only 3 per cent of unexplained variance remains at the level of localities, although it is still significant (at 0.01 level). The chi-square test of deviances $(\Delta \mathrm{df}=31, \Delta$ loglikelihood $=1173.588$ ) confirms that it is statistically significant.

4 There were 27.4 per cent of cases with missing values excluded from the regression analysis, leaving $n=12,303$. The initial analysis of variance components reveals that 73.7 per cent of variance in authoritarianism can be 
explained by differences between individuals, whereas 26.3 per cent of the variance lies at the level of localities (intra-class correlation $($ ICC $)=0.263$ ) (Table 2). The substantial variation at the level of localities means that it is necessary to search for contextual variables that would help to explain it. Inclusion of the previously described individual level variables resulted in a 9.3 per cent decrease of residual, individual level variance, and led to an even larger - 25.4 per cent reduction in intercept variance. It means that much of the observed differences between localities are due to the composition effect, ie differing individual characteristics of their young residents. In the next step, we added a number of contextual variables, which helped to achieve a 43.7 per cent reduction of intercept variance compared to the model containing only the individual level predictors - again, an improvement that is highly significant. This means that our selected contextual variables are capable of explaining a huge portion of the unexplained variation in authoritarian between localities. Only 14.4 per cent of unexplained variance remains at the level of localities, although it is still significant (at 0.01 level). The chi-square test of deviances $(\Delta \mathrm{df}=31, \Delta$ loglikelihood $=1194.808)$ confirms that it is statistically significant.

5 In this model, 24.5 per cent of the cases were excluded from the regression analysis, leaving $n=12,768$. The initial analysis of variance components reveals that 81 per cent of variance in nativism can be explained by differences between individuals, whereas 19 percent of the variance lies at the level of localities (intra-class correlation $($ ICC $)=0.19$ ) (Table 2 ). The substantial variation at the level of localities means that it is necessary to search for contextual variables that would help to explain it. Inclusion of the previously described individual level variables resulted in a 7 per cent decrease of residual, individual level variance, and led to an even larger - 19.8 per cent reduction in intercept variance. This means that much of the observed differences between localities are due to the composition effect, ie differing individual characteristics of their young residents. In the next step, we added a number of contextual variables, which helped to achieve a 12.4 per cent reduction of intercept variance compared to the model containing only the individual level predictors - again, an improvement that is highly significant. This means that our selected contextual variables are capable of explaining a huge portion of the unexplained variation in nativism between localities. Only 15 per cent of unexplained variance remains at the level of localities, although it is still significant (at 0.01 level). The chi-square test of deviances ( $\Delta \mathrm{df}=31$, $\Delta$ loglikelihood $=376.033$ ) confirms that it is statistically significant.

6 The description of 'clear' left and right is used here rather than 'extreme' or 'radical' because of the way in which the spectrum variable has been recoded to include the three codes at either end of the spectrum. It seems inappropriate to use the descriptor 'extreme' as this ought to be reserved for those at the extremities but by self-assigning toward one of the far ends is, arguably, a 'clear' preference.

7 Understandings of 'left' and 'right' vary across Europe. High levels of 'don't know' responses were found in many countries, not just post-socialist, which rendered the use of the 0-10 scale problematic hence the decision to produce a categorical representation which is more robust as it captures both those with stated positions as well as those for whom the question led to uncertainty. 